\title{
Economic Analysis of Consumptive Applications of Water
}

\author{
Harsha Beligaswatta and Ajith Panagoda
}

\section{Introduction}

Drinking, Domestic, Industrial and Irrigation water are the four main consumptive applications of water in Sri Lanka. World Health Organization [WHO] of United Nations reports thousand cubic metre of water per annum is the minimum water requirement of each human. As far as water resources are concerned, Sri Lanka is identified a rich country in the world with an average annual rainfall exceeding $1700 \mathrm{~mm}$ and annual run off of some sixty thousand million cubic metre [MCM] of water into the sea. Sri Lanka needs only 20,000 MCM of water to meet the water requirement of entire population. Water has an economic value depending on the quality, availability, storage facility and the requirements. On the other hand excess water also causes some harmful effects to the human life resulting negative economic impact.

Sri Lanka has a well developed reservoir system with a storage capacity over 5,000 MCM, especially in the dry zone. Those reservoir systems are capable of absorbing part of the flash floods and gradually release the water as per the human requirements. However, Sri Lanka faces severe scarcity of water particularly during the dry season. This can be attributed to the ineffective water management practices taking place everywhere in the country. Most of the people in the country are unaware of the fact that water has an economic price subjected to drastic changes. Proper economic analysis of different applications of water may also reveal shortcomings in the present water management system.

\section{Methodology}

This research was carried out by interviewing 100 persons representing more than 500 people belonging to different economic classes living in various part of the island. This paper is based on the information given by them.

\section{Calculation of per capita water Requirement}

\subsection{Drinking water [potable water]}

Only a little quantity of potable water is required for drinking. National Water Supply \& Drainage Board [NWS\&DB] and other related organizations had worked out that per capita drinking water requirement is five liters per day. However, recent research carried out by using 100 office workers revealed that average person drinks 2.5 to 3.5 liters of water per day. Under the hot and dry weather conditions this may be increased to 3.5 to 4.5 liters per day. According to this annual per capita drinking water requirement is $1.0-1.5$ Cubic meters.

\subsection{Domestic water requirement}

NWS\&DB has already worked out the per capita domestic water requirement per day [pcdwrpd] as follows.
Table 1-Domestic water requirement as per NWS\&DB regulations

\begin{tabular}{|l|l|}
\hline Activity & $\begin{array}{l}\text { Requirement } \\
\text { Litres per day }\end{array}$ \\
\hline Drinking & 5 \\
\hline Cooking & 10 \\
\hline Washing face, hands etc & 15 \\
\hline Bathing & 40 \\
\hline Washing clothes & 30 \\
\hline Washing pots dishes etc & 15 \\
\hline Toilets flushing & 45 \\
\hline Watering flower beds & 10 \\
\hline $\begin{array}{l}\text { Other unclassified } \\
\text { applications }\end{array}$ & 10 \\
\hline Total & 180 \\
\hline
\end{tabular}

Eng. Ajith Panagoda; Graduated in 1984 BSC Civil Engineering, University of Peraideniya, Post Graduated diploma in Irrigation and hydropurver University of Moraturwa 1993. MIE(Sri Lanka), Presenlly attached to the engineering services department of Saburagamuwa Provincial council as a dcputy director Eng. Harshapriya Beligaswatta. Graduated in 2001 specialized in civil Engineering by the University of Moratiwa. AMIE (Sri Lanka), Prescntly attached to the Sabaragamuwo Provincial Engineering services department as a design Engineer. 
If there is a scarcity of water, domestic requirement can be restricted as shown in column no 2 of table no 2 especially in rural areas.

Use of washing machines and frequent toilet flushing has resulted twenty percent increase in domestic water requirement especially in the urban areas. [Column no 3]

Table 2- Domestic water requirement under different conditions.

\begin{tabular}{|l|l|l|}
\hline Activity & $\begin{array}{l}\text { If there is a } \\
\text { scarcity of } \\
\text { water }\end{array}$ & $\begin{array}{l}\text { Water is readily } \\
\text { available Excess } \\
\text { consumption }\end{array}$ \\
\hline Drinking & 4 & 5 \\
\hline Cooking & 6 & 15 \\
\hline $\begin{array}{l}\text { Washing face, } \\
\text { hands etc }\end{array}$ & 10 & 20 \\
\hline Bathing & - & $40-250$ \\
\hline Washing clothes & 10 & 50 \\
\hline $\begin{array}{l}\text { Washing pots } \\
\text { dishes ctc }\end{array}$ & 10 & 25 \\
\hline Toilets flushing & 15 & 50 \\
\hline $\begin{array}{l}\text { Watering flower } \\
\text { beds }\end{array}$ & - & 50 \\
\hline $\begin{array}{l}\text { Other } \\
\text { unclassified } \\
\text { applications }\end{array}$ & - & 20 \\
\hline Total & 55 & $275-485$ \\
\hline
\end{tabular}

\section{Table 02}

By considering positive and negative variations it can be shown that annual domestic water requirement is about $75 \mathrm{~m} 3$ per annumn.

\subsection{Industrial water requirement}

Sri Lanka is an agricultural country and therefore Industrial water requirement is comparatively small. Rubber manufacturing and paddy processing are the main industries in the rural areas which consume a fairly large quantity of water. However, there are large numbers of water consuming industries in the urban areas. Twenty five cubic meters of water per person per anumn is assumed to be the industrial water requirement. Domestic water and industrial water satisfy same quality standards and therefore they have a same price structure.

\subsection{Irrigation water requirement}

Domestic and industrial annual per capita water requirement is less than $100 \mathrm{~m} 3$. Therefore the balance $900 \mathrm{~m}$ volume is required 3 for food production. Highly populated urban areas mainly depend on the imported or transported food itcms require less water while the food production zones require huge volume of irrigation water. As far as Sri Lanka is concerned nearly ninety five percent of the irrigation water is used for paddy cultivation. Other field crops such as sugar cane, banana and maize need less water compared to paddy. Therefore per capita irrigation requirement can be measured in terms of paddy cultivation. Per capita Irrigation requirement is directly proportional to the irrigation duty and inversely proportional to the harvest per unit area. Following specimen calculation shows the Irrigation requirement under the normal circumstances. The three dimensional bar chart describes the variation of per capita irrigation water requirement with irrigation duty and harvest per unit area.

Table 3-Calculation of per capita irrigation water requirement

\begin{tabular}{|l|l|}
\hline Description & $\begin{array}{l}\text { Quantity } \\
\text { with units }\end{array}$ \\
\hline * Assumed irrigation duty & $1200 \mathrm{~mm}$ \\
\hline * Paddy production per Ha & $4200 \mathrm{~kg}$ \\
\hline $\begin{array}{l}\text { * Per person rice } \\
\text { consumption }\end{array}$ & $0.4 \mathrm{~kg}$ \\
\hline $\begin{array}{l}\text { * Other field crops } \\
\text { (Equivalent of rice) }\end{array}$ & $0.1 \mathrm{~kg}$ \\
\hline Annual rice consumption & $183 \mathrm{~kg}$ \\
\hline * Milling Factor & 0.6 \\
\hline Rice production per Ha & $2520 \mathrm{~kg}$ \\
\hline Water requircment per Ha & $12000 \mathrm{~m}^{3}$ \\
\hline $\begin{array}{l}\text { Water requirement for } 1 \mathrm{~kg} \\
\text { of rice }\end{array}$ & $4.76 \mathrm{~m}^{3}$ \\
\hline Rice: Water Ratio & $1: 4760$ \\
\hline $\begin{array}{l}\text { Per capita Irrigation water } \\
\text { requirement }\end{array}$ & $876 \mathrm{Units}$ \\
\hline $\begin{array}{l}\text { Per capita Irrigation water } \\
\text { requirement (Duty } 1500 \mathrm{~mm} \text { ) }\end{array}$ & 1095 Units \\
\hline
\end{tabular}

* Based on my personal experience 
Graph 1-Shows the variation of irrigation demand with the irrigation duty and harvest

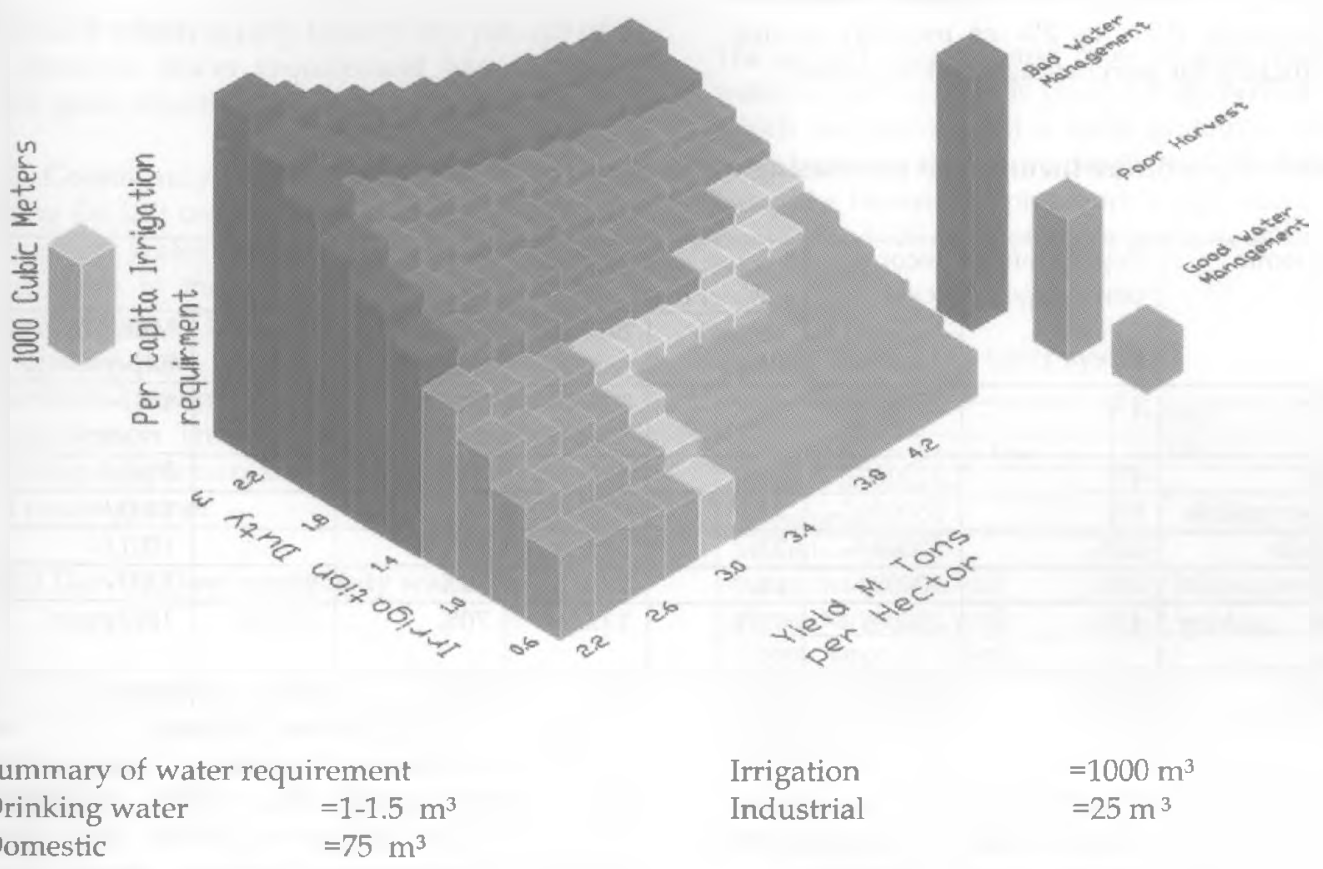

Graph 2-Human water requirement

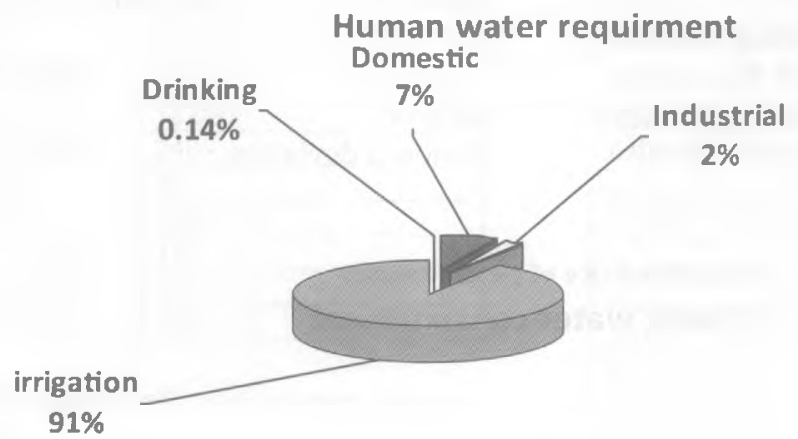

\begin{tabular}{|l|}
\hline Drinking \\
$\square$ Domestic \\
$\square$ Industrial \\
$\square$ irrigation \\
\hline
\end{tabular}

\section{Price fixing of water}

\subsection{Drinking water}

Potable water may be priced at twenty Rupees per liter to five cents per litre .Market prices or actual prices of drinking water are given in the following table No4.
Table 4- shows price of drinking water

\begin{tabular}{|l|l|}
\hline Type of potable water & Price per liter \\
\hline \#Bottled water (one liter) & 20.00 \\
\hline \#Bottled water(large) & 10.00 \\
\hline * Boiled water & 4.00 \\
\hline Treated Water & $.03-0.06$ \\
\hline * Unsafe water & $.10-.50$ \\
\hline * Needs head carrying & \\
\hline
\end{tabular}


Expenditure incurred on drinking water by different economic classes is given in table no 5. Normally $0.5 \%$ to $2 \%$ of monthly income is sufficient for purchasing drinking water.

Table 5-Expenditure incurred on purchasing water by different economic classes

\begin{tabular}{|c|c|c|c|c|c|c|c|}
\hline \multirow[t]{2}{*}{$\begin{array}{l}\text { Economic } \\
\text { class }\end{array}$} & \multirow[t]{2}{*}{$\begin{array}{l}\text { Population } \\
\text { percentage }\end{array}$} & \multirow[t]{2}{*}{$\begin{array}{l}\text { lncome } \\
\text { level }\end{array}$} & \multicolumn{5}{|c|}{$\begin{array}{l}\text { Type of Drinking } \\
\text { water used }\end{array}$} \\
\hline & & & $\begin{array}{l}\text { Bottled } \\
\text { water }\end{array}$ & $\begin{array}{l}\text { Boiled } \\
\text { water }\end{array}$ & $\begin{array}{l}\text { Natural or } \\
\text { treated }\end{array}$ & $\begin{array}{l}\text { Unsafe } \\
\text { water }\end{array}$ & $\begin{array}{l}\text { Monthly } \\
\text { Expenditure }\end{array}$ \\
\hline Elite & $1 \%$ & $250000 /-$ & $85 \%$ & $10 \%$ & $5 \%$ & - & $4141-$ \\
\hline Rich & $4 \%$ & $125000 /-$ & $30 \%$ & $45 \%$ & $25 \%$ & - & $2165 /-$ \\
\hline Upper middle & $8 \%$ & $750000 /-$ & $7 \%$ & $60 \%$ & $33 \%$ & - & $1402 /-$ \\
\hline Middle & $12 \%$ & $50000 /-$ & $2 \%$ & $50 \%$ & $48 \%$ & & $1001 /-$ \\
\hline Lower middle & $20 \%$ & $30000 /-$ & $1 \%$ & $20 \%$ & $70 \%$ & $9 \%$ & $335 /-$ \\
\hline $\begin{array}{l}\text { Just making } \\
\text { life }\end{array}$ & $45 \%$ & $20000 /-$ & $0.5 \%$ & $10 \%$ & $70 \%$ & $19.5 \%$ & $182 /-$ \\
\hline Poor & $10 \%$ & $10000 /-$ & - & $5 \%$ & $55 \%$ & $40 \%$ & $98 /-$ \\
\hline
\end{tabular}

According to the survey $3.33 \%$ of the people use bottled water while another $21.65 \%$ of the population uses boiled water. Out of the rest $60.45 \%$ find the safe water at minimum price and nearly 14.5 percent lack safe drinking water.

Expenditure incurred in purchasing drinking water shows the cross section of the income level of the different people in the country. There are rich people in the country who can expend more than five thousand Rupees on drinking water while some other people enjoy the same benefits at negligible cost. ,

Average price of drinking water $=0.0333^{\star} 10+.02165^{\star} 4+0.6045^{\star} .05+0.145^{\star}$ .10

per liter

Standard deviation $\quad=2.25$

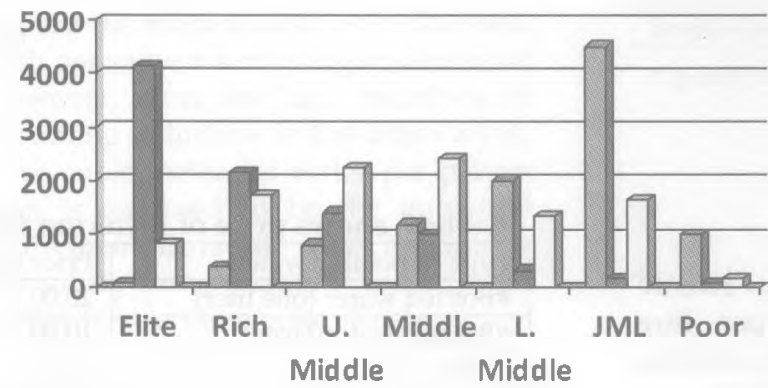




\subsection{Domestic water supply}

NWS\&DB which supply twenty five percent of the domestic water requirement has already fixeda price structure for domestic water.

\subsubsection{Community water Supply}

During the last two decades a large number of community water supply schemes were developed. This is the cheapest domestic water supply system in Sri Lanka. However, most of the gravity flow type water supply schemes experienced severe shortage of water during the dry season. This problem may be overcome by using supplementary ground water source and pump system.

\subsubsection{Gravity flow community water supply}

- Cost analysis pertaining to a typical gravity flow type conmunity water supply project is given below. Government contribution is not counted.

Table 6-Cost estimate for gravity flow type Community supply scheme

\begin{tabular}{|l|l|}
\hline Initial labour cost & $5,000 /$ \\
\hline Material cost & $1,000 /-$ \\
\hline Storage tank & $10,000 /-$ \\
\hline Internal pipe laying & $2,000 /-$ \\
\hline Total Investment & $18,000 /-$ \\
\hline Monthly interest & $240 /-$ \\
\hline O\&M charges & $60 /-$ \\
\hline Price of water & $300 /-$ \\
\hline Unit price [25 units] & $12 /-$ \\
\hline Unit price[10 units] & $30 /-$ \\
\hline Unit price[5 units] & $60 \%$ \\
\hline
\end{tabular}

\subsubsection{Community well and pump storage system}

Two meter diameter $6 \mathrm{~m}$ deep well serving twenty houses are consid ered for the analysis.

Table 7-price of water Community well

\begin{tabular}{|l|l|}
\hline Excavation of well & $25,000 /-$ \\
\hline Civil works & $75,000 /-$ \\
\hline Storage Tank & $200,000 /-$ \\
\hline Pipe laying & $100,000 /-$ \\
\hline 5 HP water pump & $100,000 /-$ \\
\hline Domestic tanks & $200,000 /-$ \\
\hline Internal pipe laying & $100,000 /-$ \\
\hline Capital cost & $800,000 /-$ \\
\hline Monthly interest & $10,000 /-$ \\
\hline Monthly yield m ${ }^{3}$ & 500 \\
\hline Pumping cost per unit & $6 /-$ \\
\hline Total cost per unit & $26 /-$ \\
\hline
\end{tabular}

\subsubsection{National Water supply and Drainage Board Supply}

The second cheapest and most reliable treated water supply service is provided by NWS\&DB which has introduced a tariff system to save more water so that more people will be able to enjoy the benefits of pipe born water. Average family needs 25 units of water and cost estimate is given below

\section{Table 8-NWS\&DB tariff system}

\begin{tabular}{|l|l|}
\hline Connection fee & $15,000 /-$ \\
\hline Storage tank and pipe line & $15,000 /-$ \\
\hline $\begin{array}{l}\text { Monthly interest on } \\
\text { investment }\end{array}$ & $375 /-$ \\
\hline Monthly rental & $50 /-$ \\
\hline Water charge [20 Units] & $67 / 50$ \\
\hline Water charge [25 Units] & $325 /-$ \\
\hline Water charge [30 Units] & $775 /-$ \\
\hline Unit Price [20 Units] & $24 / 63$ \\
\hline Unit price [25 units] & $30 /-$ \\
\hline Unit price [30 units] & $40 / 00$ \\
\hline
\end{tabular}

\subsubsection{Shallow well and pump system}

Shallow wells can not be constructed in the urban areas mainly due to the ground water contamination. It can be shown that NWS\&DB supply is cheaper than this system. Typial estimate is given below.

Table 9-Shallow well and pump system

\begin{tabular}{|l|l|}
\hline Excavation cost & $12,000 /-$ \\
\hline $\begin{array}{l}\text { Cylinder placing/Civil } \\
\text { construction cost }\end{array}$ & $20,000 /-$ \\
\hline $\begin{array}{l}\text { Pump installation } 0.75 \mathrm{hp} \\
\text { single phase water pump }\end{array}$ & $12,000 /-$ \\
\hline $\begin{array}{l}\text { Storage tank } \\
\text { Pipe laying }\end{array}$ & $10,000 /-$ \\
\hline Total cost & $2,000 /-$ \\
\hline Monthly interest & $56,000 /-$ \\
\hline Pumping charge & $700 /-$ \\
\hline Capital cost 25 units & $6 /-$ \\
\hline Capital cost 50 units & $28 / 00$ \\
\hline Unit price 25 units & $14 / 00$ \\
\hline Unit price 50 units & $34 / 00$ \\
\hline
\end{tabular}

\subsubsection{Deep well and pump system}

Actual work cost incurred for the construction of a deep well is given below. In both applications it can be shown that unit price of the water may be cut down by nearly fifty percent, if two houses can share one well.

Depth of the well $=12 \mathrm{~m}$

Diameter of well $=1.2 \mathrm{~m}$

Pumping head $=20 \mathrm{~m}$ 
Table 10-Deep well supply

\begin{tabular}{|l|l|}
\hline Excavation cost & $25,000 /-$ \\
\hline $\begin{array}{l}\text { Cylinder placing/Civil } \\
\text { construction works }\end{array}$ & $35,000 /-$ \\
\hline $\begin{array}{l}\text { Pump installation } 1.0 \mathrm{hp} \\
\text { single phase water pump }\end{array}$ & $18,000 /-$ \\
\hline $\begin{array}{l}\text { Storage tank } \\
\text { Pipe laying }\end{array}$ & $10,000 /-$ \\
\hline Total cost & $4,000 /-$ \\
\hline Monthly interest & 92,000 \\
\hline Pumping charge & $1,150 /-$ \\
\hline Capital cost 25 units & $12 /-$ \\
\hline Capital cost 50 units & $46 /-$ \\
\hline Unit price 25 units & $23 /-$ \\
\hline Unit price 50 units & $58 /-$ \\
\hline
\end{tabular}

\subsubsection{Bowser water supply}

The bowser supply is the easiest method of short term domestic supply if there is a road network available to serve the people. The bowser supply is very popular in the Middle East countries. [Water is extracted from deep aquifers and transported by consumer owned large bowsers] The long term bowser supply is 5-10 times expensive than pipe supply. The rich pcople or the, government has to bear up the cost.

\section{Table 11-Bowser supply}

\begin{tabular}{|l|l|}
\hline $\begin{array}{l}\text { Hourly charge of } 6 \mathrm{~m}^{3} \\
\text { bowser }\end{array}$ & $1,200 /-$ \\
\hline $\begin{array}{l}\text { First km loading and } \\
\text { unloading }\end{array}$ & $1 \mathrm{lur}$ \\
\hline Any subsequent $\mathrm{km}$ & 6 minuts \\
\hline Water charge & $65 /-$ \\
\hline Unit price $1 \mathrm{~km}$ & $265 /-$ \\
\hline Unit price $2 \mathrm{~km}$ & $285 /-$ \\
\hline Unit price $3 \mathrm{~km}$ & $305 /-$ \\
\hline Unit price $5 \mathrm{~km}$ & $345 /-$ \\
\hline Unit price $10 \mathrm{~km}$ & $445 /-$ \\
\hline Unit price $20 \mathrm{~km}$ & $645 /-$ \\
\hline
\end{tabular}

\subsubsection{Rain water harvesting [RWH]}

Rain water satisfy best quality standard water if it is collected in the pure form. Nearly thirty percent of the domestic requirements can be met with collected rain water. There for RWH ease pressure on NWS\&DB supply in urban areas and economic unrest in the rural areas. $A$ primitive RWH system may be constructed at negligible cost and 20-50 units of rain water may be collected annually.

As far as urban areas are concerned ground water infiltration is very low and surface run off is very high.On the other hand ground water pollution is also high. Therefore necessary legislations have now passed byparliament by making provisions for theessential RWH.
Table 12- Tentative estimate for large scale RWII project

\begin{tabular}{|l|l|}
\hline $\begin{array}{l}\text { Consider roof area of } \\
200 \mathrm{~m}^{2}\end{array}$ & \\
\hline Annual rainfall & $3000 \mathrm{~mm}$ \\
\hline Tank capacity & $20 \mathrm{~m}^{3}$ \\
\hline Specific yield & $50 \%$ \\
\hline Annual yield & $300 \mathrm{~m}^{3}$ \\
\hline Capital investments & 100,000 \\
\hline Monthly interest & $1500 /-$ \\
\hline Unit price & $60 /-$ \\
\hline
\end{tabular}

Table 13-Estimate for medium scale RWH project

\begin{tabular}{|l|l|}
\hline $\begin{array}{l}\text { Consider roof area of } 150 \\
\mathrm{~m}^{2}\end{array}$ & \\
\hline Annual rainfall & $3000 \mathrm{~mm}$ \\
\hline Tank capacity & $10 \mathrm{~m}^{3}$ \\
\hline Specific yield & $40 \%$ \\
\hline Annual yield & $180 \mathrm{~m}^{3}$ \\
\hline Capital investments & 60,000 \\
\hline Monthly interest & $900 /-$ \\
\hline Unit price & $60 \%-$ \\
\hline
\end{tabular}

Table 14-Estimate for small scale RWH project

\begin{tabular}{|l|l|}
\hline $\begin{array}{l}\text { Consider roof area of } 100 \\
\mathrm{~m}^{2}\end{array}$ & \\
\hline Annual rainfall & $3000 \mathrm{~mm}$ \\
\hline Tank capacity & $5 \mathrm{~m}^{3}$ \\
\hline Specific yicld & $35 \%$ \\
\hline Annual yield & $105 \mathrm{~m}^{3}$ \\
\hline Capital investments & 24,000 \\
\hline Monthly interest & $300 /-$ \\
\hline Unit price & $35 /-$ \\
\hline
\end{tabular}




\subsubsection{Fetching water}

Table No 15 describe price of domestic water with hauling distance and lifting height in the case of manual transport. This is very common in rural areas without pipe born water. Under extremely difficult situation price of water might be increased up to 1500 Rupees per unit.

Table 15 - Estimate for Fetching water

\begin{tabular}{|l|l|l|l|l|l|l|l|l|}
\hline $\begin{array}{l}\text { Lifting } \\
\text { height/Tauling } \\
\text { distance(in) }\end{array}$ & 10 & 20 & 50 & 100 & 200 & 500 & 1000 & 2000 \\
\hline 5 & 71 & 76 & 92 & 118 & 139 & 295 & 556 & 1076 \\
\hline 10 & 106 & 111 & 127 & 153 & 174 & 330 & 590 & 1111 \\
\hline 15 & 141 & 146 & 161 & 188 & 208 & 365 & 625 & 1146 \\
\hline 20 & 175 & 181 & 196 & 222 & 243 & 399 & 660 & 1181 \\
\hline 25 & 210 & 215 & 231 & 257 & 278 & 434 & 694 & 1215 \\
\hline 30 & 245 & 250 & 266 & 292 & 313 & 469 & 729 & 1250 \\
\hline 35 & 280 & 285 & 300 & 326 & 347 & 503 & 764 & 1285 \\
\hline 40 & 314 & 319 & 335 & 361 & 382 & 538 & 799 & 1319 \\
\hline 45 & 349 & 354 & 370 & 396 & 417 & 573 & 833 & 1354 \\
\hline 50 & 384 & 389 & 405 & 431 & 451 & 608 & 868 & 1389 \\
\hline
\end{tabular}

\subsubsection{Calculation of average price of domestic water}

Table 16 - summary of domestic water consumption estimate.

\begin{tabular}{|c|c|c|c|c|}
\hline Main Group & Sub Group & $\begin{array}{l}\text { Population } \\
\text { percentage }\end{array}$ & $\begin{array}{l}\text { Price of water } \\
\text { Rupees per Lit }\end{array}$ & Weighted factor \\
\hline \multirow[t]{4}{*}{ Community } & Group No I & $8 \%$ & 6.00 & 48 \\
\hline & Group No 2 & $9 \%$ & 12.00 & 108 \\
\hline & Group No 3 & $4 \%$ & 30.00 & 120 \\
\hline & Group No 4 & $2 \%$ & 60.00 & 120 \\
\hline \multirow[t]{4}{*}{ NWS\&DB } & Group No 1 & $8 \%$ & 25.00 & 200 \\
\hline & Group No 2 & $8 \%$ & 30.00 & 240 \\
\hline & Group No 3 & $7 \%$ & 40.00 & 280 \\
\hline & Group No 4 & $2 \%$ & 50.00 & 100 \\
\hline \multirow[t]{3}{*}{ Shallow well \& Pump } & Group No 1 & $5 \%$ & 34.00 & 170 \\
\hline & Group No 2 & $5 \%$ & 27.00 & 135 \\
\hline & Group No 3 & $5 \%$ & 20.00 & 100 \\
\hline \multirow[t]{3}{*}{ Deep well \& pump } & Group No 1 & $3 \%$ & 58.00 & 174 \\
\hline & Group No 2 & $3 \%$ & 47.00 & 141 \\
\hline & Group No 3 & $4 \%$ & 35.00 & 140 \\
\hline \multirow[t]{5}{*}{ Manual Hauling } & Group No 1 & $4 \%$ & 80.00 & 320 \\
\hline & Group No 2 & $4 \%$ & 125.00 & 500 \\
\hline & Group No 3 & $4 \%$ & 250.00 & 1000 \\
\hline & Group No 4 & $4 \%$ & 400.00 & 1600 \\
\hline & Group No 5 & $1 \%$ & 500.00 & 500 \\
\hline \multirow[t]{3}{*}{ Bowser Supply } & Group No 1 & $1 \%$ & 280.00 & 280 \\
\hline & Group No 2 & $1 \%$ & 345.00 & 345 \\
\hline & Group No 3 & $1 \%$ & 445.00 & 445 \\
\hline Free \& Subsidized & & $3 \%$ & 30.00 & 90 \\
\hline Rain Water harvesting & & $2 \%$ & 40.00 & 80 \\
\hline \multirow[t]{2}{*}{ Unclassified } & & $2 \%$ & 30.00 & 60 \\
\hline & & & & 7296 \\
\hline
\end{tabular}


Average price of domestic water $=72.96$ Rupees $\quad$ Standard deviation $=109$ rupees

Graph No 5

\section{Price of domestic water}

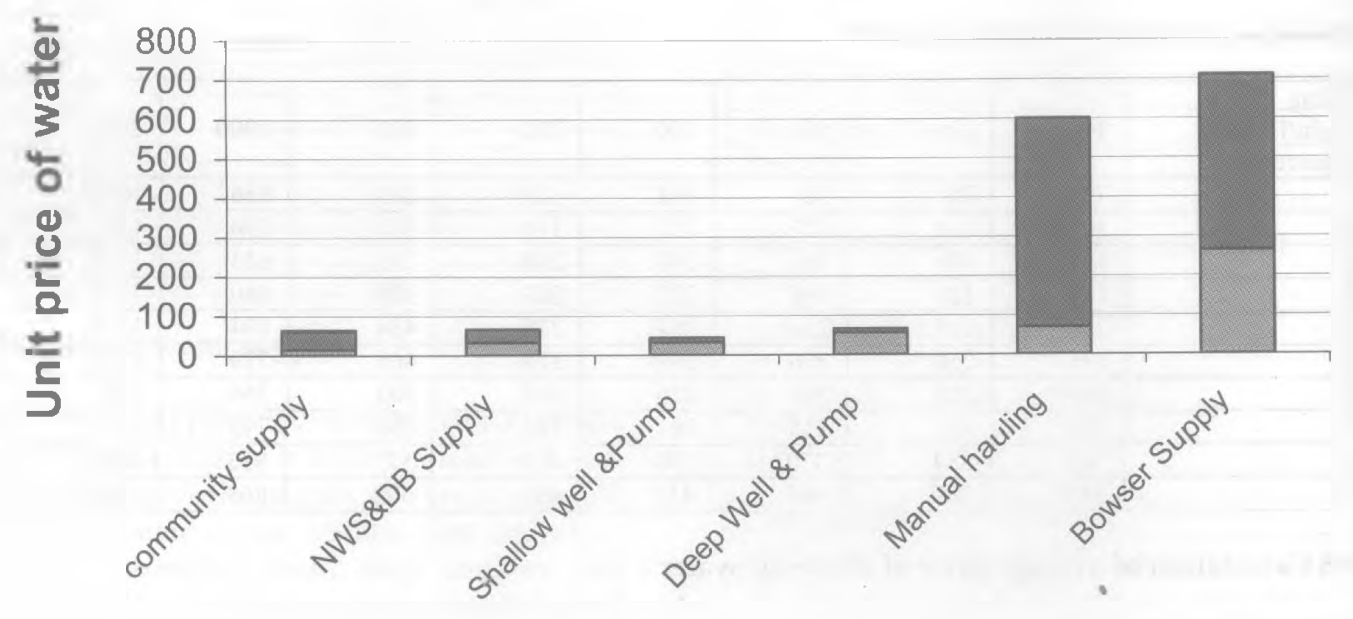

\subsubsection{Fixing a price for Irrigation water}

Most of the large scale irrigation schemes may be treated as multipurpose projects. Irrigation as well as hydropower, water supply, flood control, navigation recreation and aquatic resources are the main benefits that could be derived from a large scale reservoir project. Negative economic impacts such as environmental degradation and desturbing the ecological are also caused balance by the large multipurpose water resources development projects.

\subsubsection{Mahaweli Multipurpose project}

As far as Mahaweli multipurpose water resources development project is concerned, cost benefit analysis can't be carried out by isolating irrigation component. Mahaweli hydropower system has so far been able to generate massive energy of some $37,500 \mathrm{GWh}$ worth 600 billion rupees. Accelerated Mahaweli project mainly focused on hydropower development and nearly two third of the benefits should be in the form of hydropower while the balance one third may be in the form of irrigation benefits. Based on this simple assumption unit price of irrigation water can be calculated as follows.
Official web site of the Mahaweli Authority reveals that present worth of the total project cost in 2006 is 89.9 billion rupees. However, present worth of the project is more than Rs 750 billion Sri Lankan rupees mainly due to the high inflation rates prevailed in the country.

Table 17- Mahaweli project cost benefit analysis

\begin{tabular}{|l|l|}
\hline $\begin{array}{l}\text { * Mahaweli Project cost in year } \\
1984\end{array}$ & $\begin{array}{l}50 \text { billion } \\
\text { Rupees }\end{array}$ \\
\hline Internal rate of return & $12 \%$ \\
\hline Present worth of project (2008) & $\begin{array}{l}759 \text { billion } \\
\text { Rupees }\end{array}$ \\
\hline $\begin{array}{l}\text { Present worth of Hydropower } \\
\text { benefits (2008) }\end{array}$ & 600 billion \\
\hline $\begin{array}{l}\text { Present worth of Irrigation } \\
\text { benefits(2008) }\end{array}$ & 300 billion \\
\hline Value of surplus benefits & 900 billion \\
\hline Surplus return & 141 Billion \\
\hline $\begin{array}{l}\text { ** Newly cultivated area under } \\
\text { the Mahaweli project }\end{array}$ & $100,000 \mathrm{Ha}$ \\
\hline Assumed Irrigation Duty & $1500 \mathrm{~mm}$ \\
\hline Volume of water issued & $75 \mathrm{BCM}$ \\
\hline Price of water & $\begin{array}{l}4.00 \mathrm{Rs} \text { per } \\
\text { Unit }\end{array}$ \\
\hline
\end{tabular}




\subsubsection{Uda Walawe Project}

Uda Walawe Multipurpose reservoir was built in 1969 mainly for irrigation. Uda Walawe reservoir has 3 Numbers of 2 MW hydroelectric turbines in order to harness the available energy in the irrigation water. Under the most unfavorable circumstances Uda Walawe power station had been able to generate 585 GWh worth 9360 Million Rupees. Project cost benefit analysis is given below.

Table 18-Uda Walawe project cost benefits analysis

\begin{tabular}{|l|l|}
\hline Project cost in Year 1969 & $\begin{array}{l}165 \text { Million } \\
\text { Rupees }\end{array}$ \\
\hline Rehabilitation cost in year 1987 & $\begin{array}{l}1200 \text { Million } \\
\text { Rupees }\end{array}$ \\
\hline Internal rate of return & $2 \%$ billion \\
\hline Present worth of the project & 26.8 billion \\
\hline $\begin{array}{l}\text { Present worth of the left Bank } \\
\text { Extension project 2005 }\end{array}$ & 10.0 Billion \\
\hline Hydropower benefits & 9.36 billion \\
\hline Irrigation benefits & 27.44 Billion \\
\hline Water issued & 17.55 BCM \\
\hline Price of water without O\&M & $\begin{array}{l}1.57 \text { Rupees } \\
\text { per unit }\end{array}$ \\
\hline $\begin{array}{l}\text { Price of water with operation } \\
\text { and maintenance charges }\end{array}$ & $\begin{array}{l}2.00 \text { Rupees } \\
\text { per unit }\end{array}$ \\
\hline
\end{tabular}

\subsubsection{Alternative price structure based on potential energy of water}

Comparatively low prices of water have been resulted mainly due to the very low oil prices prevailed in the world during the last few decades. During the last eight years oil prices increased nearly by six hundred percent. Electricity prices have increased by approximately
$300 \%$ Largest non consumptive application of water is hydropower and therefore economic analysis may be carried out by considering a unit of water stored in medium level Victoria and Samanalawewa reservoirs.

Table 19-Economic value of water based on potential energy

\begin{tabular}{|l|l|l|}
\hline $\begin{array}{l}\text { Reservoir } \\
\text { Description }\end{array}$ & Victoria & Samanalawewa \\
\hline Elevation & $430 \mathrm{~m} \mathrm{MSL}$ & $440 \mathrm{~m}$ MSL \\
\hline Effective head & $264 \mathrm{~m}$ & $340 \mathrm{~m}$ \\
\hline $\begin{array}{l}\text { Energy Stored } \\
\text { in one unit of } \\
\text { water of }\end{array}$ & $0.66 \mathrm{kWh}$ & $0.85 \mathrm{kWh}$ \\
\hline $\begin{array}{l}\text { Oil based } \\
\text { price } \\
\text { electricity }\end{array}$ & 10.56 & 13.60 \\
\hline $\begin{array}{l}\text { Economic } \\
\text { price of water }\end{array}$ & $\begin{array}{l}\text { More than } \\
\text { priso }\end{array}$ & $\begin{array}{l}\text { More than } \\
14.00\end{array}$ \\
\hline
\end{tabular}

As far as water resources planning is concerned, market price of irrigation water may be taken as six rupees per unit.

Farmers estimate on paddy cultivation is given below.

Table 20- Farmers estimate on irrigation

\begin{tabular}{|l|l|}
\hline Harvest per $\mathrm{Ha}$ & $\begin{array}{l}4200 \mathrm{~kg} \text { Paddy } \\
2500 \mathrm{~kg} \text { of rice }\end{array}$ \\
\hline Price of rice & $56 \mathrm{Rs}$ per kg \\
\hline Income & 140,000 Rupees per ha \\
\hline Irrigation duty water & $1200 \mathrm{~mm}$ \\
\hline $\begin{array}{l}\text { Affordable of income } \\
\text { charge }\end{array}$ & $8400 /-$ \\
\hline Water used & 12000 Units \\
\hline Affordable price & 70 cents per unit \\
\hline & Say 1 Rupees per unit \\
\hline
\end{tabular}

\subsection{Table 21-Summary of all consumptive applications of water}

Following table summarized the water requirement estimate at national level

\begin{tabular}{|l|l|l|l|l|}
\hline Application of water & $\begin{array}{l}\text { Unit price } \\
\text { (Rupees) }\end{array}$ & $\begin{array}{l}\text { Standard deviation } \\
\text { (Rupees) }\end{array}$ & Quantity[MCM] & $\begin{array}{l}\text { Amount Billion } \\
\text { Rupees }\end{array}$ \\
\hline Drinking & $1,250 /-$ & $2,250 /-$ & 25 & 31.25 \\
\hline Domestic(Average) & $72 / 75$ & $109 /-$ & 1,500 & 109.125 \\
\hline $\begin{array}{l}\text { Domestic(Favorable) } \\
\text { With RWH }\end{array}$ & $40 / 00$ & $20 /-$ & 1,200 & 80.00 \\
\hline Industrial & $72 / 75$ & - & 100 & 7.275 \\
\hline Irrigation (Actual) & $5 / 00$ & - & 18,000 & 90.00 \\
\hline Irrigation(Subsidized) & $1 / 00$ & - & 18,000 & 18.00 \\
\hline Total & & & & $165-200$ \\
\hline
\end{tabular}




\section{Conclusion}

Ground water contamination has become a serious problem in urban areas. Direct waste water disposal is not permitted indeveloped countries like the United Kingdom. Clean water act should be passed without further delay so that poor people of the country will enjoy the benefits of quality drinking water at cheap prices.

Drinking water that confirms with WHO standard may be priced at 5 cents per litre to 25 Rupees per litre. This variation has to be minimized, [The standard deviation of prices of drinking and domestic water is higher than the average prices and this has resulted a negative skewness in the price distribution.]

People living in Anuradhapura, Polonnaruwaand few other districts have experienced chronic renal failure mainly due to the bad quality of drinking water. Bottled water industry may be developed so that low income people in the affected areas will be able to buy potable water at a reasonable price.

Many man months are lost due to the short term water born diseases suchas cholera. Disinfection methods like Ultra violet radiation and Ozonization may be used for purifying potable water.

Price of domestic water also varies from 6 to 600 rupees per unit. Most of the privileged rich people can enjoy reliable domestic supply at a reasonable price mainly due to the water service provided by NWS\&DB. Therefore, additional cost incurred on domestic water has to be born by the poor people in the village.

During severe droughts, which is common natural disaster in Sri Lanka, government normally supply free water for the affected people. Short term bowser supply is an expensive method and this situation may be controlled by having large number of decentralized medium scale water supply projects comprising of large storage tanks. Rain water harvesting may be popularized among the high income groups.

Most of Sri Lankan dislike the term "Irrigation water taxation". Economic decline in the country can be partly attributed to this myopic notion of the people. All the same, the government had already made a massive investment on irrigation projects. It can be shown that irrigation water may be priced at 2 Rupees per unit to 12 Rupees depending on the availability of water and various other factors.

However, agricultural crop cultivation is not a profitable industry in Sri Lanka. Therefore poor farming community cannot bear up the actual cost incurred on irrigation water. Equitable distribution of water among the farmers has become a serious problem and this has resulted active discrimination among the farming communities. This problem may be overcome by introducing a reasonable tax system on irrigation water so that excess consumer may bear up the additional cost incurred while starving people may also enjoy the benefits of irrigation water.

As far as the Mahaweli project is concerned project cost has already been recovered in terms of hydropower and returns during the next twenty years will definitely contribute to boost the economy. Effective watershed management as well as effective watermanagement is also a sine qua non for sustainable development.

\section{Reference}

1. Mahaweli Authority official web site

2. Water supply and sanitation- prof. Dunkan Mara paper presented at Jubilee congress -2002

3. NWS\&DB price list-2005

4. Hydropower development in Sri Lanka by Eng H.B. Jayasekara-Kulasinghe felicitation volume

5. Annual Report Energy conservation fund-2004

\section{Acknowledgements}

1. Dr T.M Pallewatta

2. Eng M.C Opatha

3. Eng W.N Premasiri NWS\&DB Ratnapura 